\title{
The Impact of Social Media Marketing Activities on Consumer Equity: Evidence from Luxury Brand
}

\author{
Mariam Amin ${ }^{1}$ and Francis Pol C. Lim $^{2}$ \\ ${ }^{1}$ SMC University, Zug, Switzerland \\ ${ }^{2}$ SMC Education Group, Pope Urbanus VIII Street, B'Kara BKR 1425, Malta \\ ${ }^{1}$ mariam.amin@student.swissmc.ch, ${ }^{2}$ fpl@smceducation.eu
}

\begin{abstract}
Most of the studies have examined the concept of social media marketing activities in the context of customer intention or on customer satisfaction while the role of customer equity when examining the impact of social media marketing activities on consumer intention is limitedly deliberated. Thus, this paper aims to examine how social media marketing efforts influence consumer equity and the intention of luxury brand users in Pakistan. The data were collected from two hundred fifty respondents and Partial Least Squares Structural Equation Modeling (PLS-SEM) was used to estimate the complex relationship models. The results showed that social media marketing has a positive and significant relationship with value relationships and brand equity. Moreover, all three drivers such as value, relationship, and brand equity have a positive and significant relationship with purchase intention and consumer equity. Thus, the study gives valuable implications to key individuals in such fields including brand managers and marketers. This paper can help in the examination of the potential and strength of marketing strategies and actions. Moreover, the study proposes strategies that can help improve brand performance by explaining factors related to purchasing intention and customer equity. Furthermore, the results can help the marketers in forecasting customer purchasing intention and manage social activities accordingly.
\end{abstract}

Keywords: Social media marketing activities, Customer equity, Purchase intention, Luxury brand

\section{Introduction}

In today's world, several people are connected in real-time through social media. Social media has become one of the traditional ways for finding new information, for generating new social and economic consequences [1]. Despite using it for personal uses it has been used by the leading companies and brands to reach and engage with their consumers [2]. It has been used by the companies externally for customer management, promotions, marketing and internally used to communicate with the employees [1]. From the customer perspective, it is considered as one of the more trusted sources compared to traditional mass media [3]. The main advantage of this new media i.e., social media is the level of interaction and its speed. Furthermore, consumer-preferred brands that are accessible in social media provide sufficient content [4].

Article history:

Received (March 15, 2021), Review Result (April 20, 2021), Accepted (August 5, 2021) 
In this new era, social media continues to expand as a channel for marketing products and services reaching around two-thirds of the internet users [2]. This medium provides opportunities for brand building, brand reputation, and brand management. Social media marketing was able to gain significant attention in the past few years [1]. The recall rate of social media advertisement in comparison to the conventional advertisement is $55 \%$ higher and according to the [5] report, social media influenced $90 \%$ of all purchases. Social media marketing reports show that $87 \%$ of the marketers concluded that social media marketing helped them to generate more exposure for their business and also helped them to increase traffic and gained new partnerships [6].

Indeed, social media emerged as a new platform where organizations, people as well as governments can interact with each other socially, educationally, commercially, politically and can exchange their thoughts, information on products and services. Moreover, this platform is also used by firms for different marketing practices such as advertising, branding, Electronic Word-of-Mouth (e-WOM), and customer relationship management [7]. Social media marketing, due to its interactive nature becomes the modern stage of the development of firm-customer communication [8]. Thus, social media not only helps firms to achieve their marketing aims but also helps in shaping consumers' perceptions and motivating them to buy products and services [7].

As a marketing tool, social media is used as a more network-focused approach by companies to manage customer relationships. The firms can engage their customers in conversations which helps them to enhance their customer equity which plays a vital role in the firm's long-term value and guarantees a firm's success in the long run [9].

In addition, social media marketing allows consumers as well as firms to work together to develop new business models, products and services, values [10]. Social media marketing also allows customers to associate their emotions towards a certain brand [11]. Furthermore, by providing a platform for users to share their information or ideas related to products and services, it elevates the brand value. Thus, it is of immense importance to study the role of social media marketing activities on consumer equity and how these activities influence consumer intentions [10].

\section{Literature review}

\subsection{Social media marketing activities and purchase intention}

Marketing activities are frequently being conducted on social media platforms including but are not limited to blogs, Facebook, Instagram, and YouTube [23]. Social media marketing has obvious advantages compared with traditional marketing techniques [24]. For this reason, some research focuses on such topics including their relationship to purchase intention [25][26].

The association between social media marketing activities and purchase intention is examined among luxury brands customers and applied multiple regression techniques [10]. They concluded that trendiness, customization, and entertainment affect customer purchase intention and suggested that more luxury brands should employ social media marketing. The association among luxury brands customers and concluded that social media marketing activities have a significant effect on brand equity [2]. The study suggested that brands should promote these social media marketing activities on social media sites. In the context of luxury fashion brands, they also reported that social media marketing efforts were able to provide a positive and significant effect on consumer purchase intention [12]. The study suggested that 
the management of luxury fashion brands should employ social media marketing as this helps improve customer value.

In the context of the tourism industry, social media marketing activities significantly affects consumer behavioral intentions [13]. In the context of the e-commerce industry, social media marketing activities positively affect the brand equity and purchase intention of consumers [14]. On the other hand, a study in the airline industry concluded that social media marketing undertakings positively affect brand equity including brand awareness, brand image, and purchase intention [1]. Furthermore, studies in the hotel services industry showed that social media marketing activities have a significant effect on customer revisit intention [10].

\subsection{Drivers of customer equity and purchase intention}

The effect of drivers of customer equity i.e., relationship equity, value equity, and brand equity on purchase intention is studied in a professional soccer context [15]. The result showed that brand equity and relationship equity have a noteworthy influence on consumer purchase intention. The study recommended that sport marketing practitioners should focus on effective brand management and relationship management as it will help to improve consumer intentions towards the brand. Another study also reported that value equity has a significant influence on repurchase intention whereas brand equity and relationship equity do not affect consumer repurchase intention [10]. The study concluded that the findings will help the distribution companies to predict their consumers repurchase intention more precisely and also guide them in managing their marketing activities and assets.

The association between the drivers of customer equity and customer lifetime value is examined by [16]. The data is collected from 350 social media users of Macau in China and Hong Kong. The result showed that all the three drivers of equity i.e., value, relationship, and brand equity have a significant relationship with customer lifetime value. The effect of drivers of customer equity on purchase intention is examined by [10]. The data is collected from customers of Bank X in Tehran. The result showed that brand equity has an insignificant effect on purchase intention whereas value equity and relationship equity have a significant effect on purchase intention. They further suggested that if the firms invest in these customer equity drivers it will help them to improve their customer loyalty which results in repurchase intention.

\section{Methodology}

The research approach for this study is quantitative. The study focuses on young consumers of Pakistan who use a certain brand. Two hundred fifty respondents were selected to participate in the study.

In this study, the data is collected using a survey questionnaire. The questionnaire is developed in English and is validated by the field experts. The questionnaire is comprised of 10 variables and in total 34 items are asked. The items of the questionnaire are adapted from past studies and are measured on a five-point Likert scale in which 1 is strongly disagree; 2 is disagree, 3 is neutral, 4 is agree and 5 is strongly agree.

[Table 1] represented the demographic profile of the respondents. The outcome showed that 162 of the respondents were male whereas 88 of the respondents were female. Around $44 \%$ of the respondents fall in the age bracket of $25-30$. Moreover, $68 \%$ of the respondents are postgraduate and $49 \%$ of them have a household income of $50-74 \mathrm{k}$. The majority of the respondents i.e., $63 \%$ spend around 1-3hours on social media. 
Table 1. Respondent's profile $(\mathrm{N}=250)$

\begin{tabular}{|c|c|c|}
\hline Demographic items & Frequency & Percentile \\
\hline \multicolumn{3}{|c|}{ Gender } \\
\hline Male & 162 & $65 \%$ \\
\hline Female & 88 & $35 \%$ \\
\hline \multicolumn{3}{|l|}{ Age } \\
\hline $18-25$ & 64 & $25 \%$ \\
\hline $26-30$ & 109 & $44 \%$ \\
\hline $31-35$ & 55 & $22 \%$ \\
\hline 36 or above & 22 & $9 \%$ \\
\hline \multicolumn{3}{|c|}{$\begin{array}{l}\text { Social Media Using Intensity (Per day) } \\
\end{array}$} \\
\hline less than 1 hour & 38 & $15 \%$ \\
\hline $1-3$ hours & 156 & $63 \%$ \\
\hline more than 3 hours & 56 & $22 \%$ \\
\hline \multicolumn{3}{|c|}{ Household Income } \\
\hline$>30 \mathrm{~K}$ & 20 & $8 \%$ \\
\hline $31-49 \mathrm{~K}$ & 45 & $18 \%$ \\
\hline $50 \mathrm{~K}-74 \mathrm{~K}$ & 122 & $49 \%$ \\
\hline Above $74 \mathrm{~K}$ & 63 & $25 \%$ \\
\hline \multicolumn{3}{|c|}{ Education level } \\
\hline Undergraduate & 28 & $11 \%$ \\
\hline Graduate & 48 & $19 \%$ \\
\hline Post Graduate & 170 & $68 \%$ \\
\hline Others & 4 & $2 \%$ \\
\hline
\end{tabular}

At the initial level, the purpose of marketing by firms is to inform their consumers about their offerings related to their products and services. It is a multi-dimensional process and involves several strategies; however, the primary objective of any marketing is to improve the firms' profitability and sales [10]. The use of social media for marketing purposes by the brands is to build customer relationships and improve profits, so it is also expected that these activities will also affect the drivers of customer equity i.e., value equity, relationship equity, brand equity. Based on the above discussion the hypothesis of the study is:

H1: Social media marketing activities have a significant effect on value equity.

$\mathrm{H} 2$ : Social media marketing activities have a significant effect on relationship equity.

H3: Social media marketing activities have a significant effect on brand equity.

To calculate, customer equity has to link marketing input to customer reactions [17]. The RLZ model incorporates a customer-specific brand switching matrix to examine customer equity drivers and tested this model in the context of the airline industry. They reported that all three drivers' values, relationships, and brands are related to customer equity. The same model is used by several studies to measure customer equity [10]. To prove the RLZ model and to identify the constructs of each customer equity driver in the context of the telecommunication industry the following hypothesis is developed:

H4: Value equity has a significant effect on customer equity.

H5: relationship equity has a significant effect on customer equity.

H6: Brand equity has a significant effect on customer equity. 
To predict the consumer's future buying pattern, it is necessary to match their attitudes and action. Previous studies prove that in design making process attitude acts as the antecedent. Similarly, customer activity drivers also play an important role in shaping consumer purchase intention. Therefore, in this study, we also examine the effect of drivers of customer equity on consumer purchase intention and the effect of purchase intention with customer equity, so the hypothesis we developed is:

H7: Value equity has a significant effect on purchase intention.

H8: relationship equity has a significant effect on purchase intention.

H9: Brand equity has a significant effect on purchase intention.

H10: purchase intention has a significant effect on customer equity.

\section{Data analysis}

The technique used in this study is partial least squares structural equation modeling (PLSSEM) is used and analysis is performed on smart PLS software version 3.0. The PLS-SEM is appropriate for the study that has a small sample size, few variables and the purpose is to examine the relationship between them.

\subsection{Measurement model}

In the measurement model, the convergent validity and discriminant validity are analyzed. The convergent validity is confirmed by looking at the values of (i) individual item reliability (ii) Cronbach's $\alpha$ (iii) composite reliability (iv) average variance extracted (AVE). [Table 2] depicts the results of convergent validity and showed that the individual item reliability of all the variables is higher than 0.55 which meets the criteria given by [18]. The consistency of the data is explained by the Cronbach's $\alpha$, and composite reliability, and seen from the results all the variables have values greater than 0.6 satisfying the criteria given by [19]. The AVE explains the change in factors and the value should be greater than 0.5 . The result shows that all the variables have an AVE value greater than 0.5 which is by the benchmark given by [20]. Thus, the above results affirm the convergent validity.

Table 2. Measurement model results

\begin{tabular}{|c|c|c|c|c|c|}
\hline Constructs & Items & Loadings & $\begin{array}{c}\text { Cronbach's } \\
\text { Alpha }\end{array}$ & $\begin{array}{l}\text { Composite } \\
\text { Reliability }\end{array}$ & $\begin{array}{l}\text { Average Variance } \\
\text { Extracted (AVE) }\end{array}$ \\
\hline \multirow{4}{*}{$\mathrm{BE}$} & BE1 & 0.896 & \multirow{4}{*}{0.895} & \multirow{4}{*}{0.896} & \multirow{4}{*}{0.683} \\
\hline & BE2 & 0.963 & & & \\
\hline & BE3 & 0.778 & & & \\
\hline & BE4 & 0.903 & & & \\
\hline \multirow{2}{*}{$\mathrm{CE}$} & CE1 & 0.804 & \multirow{2}{*}{0.927} & \multirow{2}{*}{0.932} & \multirow{2}{*}{0.523} \\
\hline & CE2 & 0.922 & & & \\
\hline \multirow{3}{*}{ PI } & PI1 & 0.867 & \multirow{3}{*}{0.905} & \multirow{3}{*}{0.903} & \multirow{3}{*}{0.757} \\
\hline & PI2 & 0.925 & & & \\
\hline & $\mathrm{PI} 3$ & 0.816 & & & \\
\hline \multirow{3}{*}{$\mathrm{RE}$} & RE1 & 0.964 & \multirow{3}{*}{0.894} & \multirow{3}{*}{0.900} & \multirow{3}{*}{0.651} \\
\hline & RE2 & 0.991 & & & \\
\hline & RE3 & 0.862 & & & \\
\hline
\end{tabular}




\begin{tabular}{|c|c|c|c|c|c|}
\hline & RE4 & 0.962 & & & \\
\hline & RE5 & 0.956 & & & \\
\hline \multirow{16}{*}{ SMMA } & Custom1 & 0.701 & \multirow{16}{*}{0.920} & \multirow{16}{*}{0.807} & \multirow{16}{*}{0.534} \\
\hline & Custom2 & 0.774 & & & \\
\hline & Custom3 & 0.622 & & & \\
\hline & Ent1 & 0.721 & & & \\
\hline & Ent2 & 0.751 & & & \\
\hline & Ent3 & 0.605 & & & \\
\hline & Ent4 & 0.693 & & & \\
\hline & Int 1 & 0.697 & & & \\
\hline & Int2 & 0.608 & & & \\
\hline & Int3 & 0.632 & & & \\
\hline & Int 4 & 0.635 & & & \\
\hline & Trend1 & 0.719 & & & \\
\hline & Trend2 & 0.605 & & & \\
\hline & WOM1 & 0.616 & & & \\
\hline & WOM2 & 0.611 & & & \\
\hline & WOM3 & 0.604 & & & \\
\hline \multirow{4}{*}{$\mathrm{VE}$} & VE1 & 0.722 & \multirow{4}{*}{0.837} & \multirow{4}{*}{0.797} & \multirow{4}{*}{0.557} \\
\hline & VE2 & 0.933 & & & \\
\hline & VE3 & 0.915 & & & \\
\hline & VE4 & 0.929 & & & \\
\hline
\end{tabular}

Note: BE means Brand Equity, CE means consumer Equity, SMMA means social media marketing Activities, RE means relationship Equity, PI means purchase intention, VE means Value Equity

After the confirmation of convergent validity, discriminant validity is confirmed by looking at the values of (i) correlation matrix (ii) loading and cross-loadings (iii) heterotrait-monotrait ratio of correlations (HTMT). [Table 3] depicts the result of the correlation matrix and as the result showed the diagonal values (square root of AVE) should be greater than the off-diagonal value satisfying the benchmark given by [20]. Table 4 showed the result of loadings and crossloadings and as seen from the results all the variables have the highest value in their construct and have differences higher than 0.1 satisfying the standards given by [21]. [Table 5] showed the results of HTMT and as seen from the results all the values are less than 0.85 satisfying the benchmark given by [22]. Thus, the above results affirm the discriminant validity.

Table 3. Fornell-Larcker criterion

\begin{tabular}{|c|c|c|c|c|c|c|}
\hline & BE & CE & PI & RE & SMMA & VE \\
\hline BE & 0.827 & & & & & \\
\hline CE & 0.824 & 0.723 & & & & \\
\hline PI & 0.801 & 0.655 & 0.870 & & & \\
\hline RE & 0.712 & 0.686 & 0.521 & 0.807 & & \\
\hline SMMA & 0.503 & 0.591 & 0.414 & 0.590 & 0.678 & \\
\hline VE & 0.729 & 0.556 & 0.348 & 0.742 & 0.578 & 0.746 \\
\hline
\end{tabular}

Note: BE means Brand Equity, CE means consumer Equity, SMMA means social media marketing Activities, RE means relationship Equity, PI means purchase intention, VE means Value Equity 
Table 4. Loadings and cross-loadings

\begin{tabular}{|c|c|c|c|c|c|c|}
\hline & BE & CE & PI & RE & SMMA & VE \\
\hline BE1 & 0.896 & 0.789 & 0.816 & 0.674 & 0.507 & 0.532 \\
\hline BE2 & 0.963 & 0.745 & 0.816 & 0.674 & 0.507 & 0.532 \\
\hline BE3 & 0.778 & 0.753 & 0.698 & 0.475 & 0.229 & 0.694 \\
\hline BE4 & 0.903 & 0.705 & 0.698 & 0.475 & 0.229 & 0.694 \\
\hline Custom1 & 0.425 & 0.410 & 0.433 & 0.409 & 0.701 & 0.419 \\
\hline Custom2 & 0.371 & 0.277 & 0.393 & 0.331 & 0.774 & 0.312 \\
\hline Custom3 & 0.239 & 0.363 & 0.206 & 0.487 & 0.622 & 0.303 \\
\hline Ent1 & 0.573 & 0.598 & 0.501 & 0.449 & 0.721 & 0.691 \\
\hline Ent2 & 0.488 & 0.639 & 0.504 & 0.587 & 0.751 & 0.707 \\
\hline Ent3 & 0.147 & 0.110 & 0.312 & 0.303 & 0.605 & 0.198 \\
\hline Ent4 & 0.218 & 0.148 & 0.259 & 0.108 & 0.693 & 0.175 \\
\hline Int1 & 0.199 & 0.216 & 0.141 & 0.214 & 0.697 & 0.250 \\
\hline Int2 & 0.360 & 0.373 & 0.157 & 0.503 & 0.608 & 0.167 \\
\hline Int3 & 0.174 & 0.254 & 0.286 & 0.414 & 0.632 & 0.209 \\
\hline Int4 & 0.274 & 0.256 & 0.284 & 0.411 & 0.635 & 0.217 \\
\hline Trend1 & 0.607 & 0.718 & 0.242 & 0.676 & 0.719 & 0.709 \\
\hline Trend2 & 0.121 & 0.156 & 0.442 & 0.183 & 0.605 & 0.121 \\
\hline WOM1 & 0.363 & 0.109 & 0.310 & 0.112 & 0.616 & 0.107 \\
\hline WOM2 & 0.125 & 0.107 & 0.099 & 0.100 & 0.611 & 1.070 \\
\hline WOM3 & 0.253 & 0.101 & 0.406 & 0.204 & 0.604 & 0.106 \\
\hline PI1 & 0.804 & 0.544 & 0.867 & 0.391 & 0.103 & 0.289 \\
\hline PI2 & 0.769 & 0.667 & 0.925 & 0.645 & 0.122 & 0.353 \\
\hline PI3 & 0.783 & 0.491 & 0.816 & 0.304 & 0.142 & 0.264 \\
\hline RE1 & 0.715 & 0.957 & 0.484 & 0.964 & 0.513 & 0.857 \\
\hline RE2 & 0.715 & 0.903 & 0.484 & 0.991 & 0.513 & 0.857 \\
\hline RE3 & 0.296 & 0.674 & 0.281 & 0.862 & 0.172 & 0.689 \\
\hline RE4 & 0.674 & 0.891 & 0.410 & 0.962 & 0.734 & 0.766 \\
\hline RE5 & 0.674 & 0.842 & 0.410 & 0.956 & 0.734 & 0.766 \\
\hline VE1 & 0.276 & 0.495 & 0.101 & 0.407 & 0.027 & 0.722 \\
\hline VE2 & 0.826 & 0.933 & 0.508 & 0.919 & 0.627 & 0.933 \\
\hline VE3 & 0.621 & 0.825 & 0.176 & 0.726 & 0.687 & 0.915 \\
\hline VE4 & 0.721 & 0.785 & 0.176 & 0.726 & 0.687 & 0.929 \\
\hline CE1 & 0.644 & 0.804 & 0.667 & 0.391 & 0.203 & 0.299 \\
\hline CE2 & 0.769 & 0.922 & 0.725 & 0.545 & 0.222 & 0.353 \\
\hline & & & & & & \\
\hline
\end{tabular}

Table 5. Heterotrait-Monotrait Ratio (HTMT)

\begin{tabular}{|c|c|c|c|c|c|c|}
\hline & BE & CE & PI & RE & SMMA & VE \\
\hline BE & & & & & & \\
\hline CE & 0.822 & & & & & \\
\hline PI & 0.803 & 0.657 & & & & \\
\hline RE & 0.709 & 0.796 & 0.547 & & & \\
\hline SMMA & 0.507 & 0.603 & 0.362 & 0.563 & & \\
\hline VE & 0.655 & 0.666 & 0.294 & 0.789 & 0.543 & \\
\hline
\end{tabular}




\subsection{Structural model}

After the confirmation of the measurement model, the structural model is analyzed. Table 6 depicts the result of the structural model and each path in the table represents the hypothesis. The result is assessed by looking at (i) coefficient value (ii) coefficient sign (iii) significance level. The outcome showed that all the 10 developed hypotheses are accepted as the P-value is less than 0.05 and the association between the variables is positive.

Table 6. Standardized regression weights for the research model

\begin{tabular}{|c|c|c|c|c|c|}
\hline Hypothesis & $\begin{array}{c}\text { Regression } \\
\text { Path }\end{array}$ & Effect type & SRW & P Values & Remarks \\
\hline H1 & SMMA -> VE & Direct Effect & 0.578 & 0.000 & Supported \\
\hline H2 & SMMA -> RE & Direct Effect & 0.590 & 0.000 & Supported \\
\hline H3 & SMMA -> BE & Direct Effect & 0.503 & 0.000 & Supported \\
\hline H4 & VE -> CE & Direct Effect & 0.102 & 0.007 & Supported \\
\hline H5 & RE -> CE & Direct Effect & 0.212 & 0.010 & Supported \\
\hline H6 & BE -> CE & Direct Effect & 0.506 & 0.048 & Supported \\
\hline H7 & VE -> PI & Direct Effect & 0.489 & 0.000 & Supported \\
\hline H8 & RE -> PI & Direct Effect & 0.340 & 0.008 & Supported \\
\hline H9 & BE -> PI & Direct Effect & 0.308 & 0.000 & Supported \\
\hline H10 & PI -> CE & Direct Effect & 0.432 & 0.007 & Supported \\
\hline
\end{tabular}

\subsection{Discussion}

The first three hypotheses related to the effect of social media marketing activities on drivers of customer equity i.e., value, relationship, and brand are accepted. The result shows that social media marketing activities have a significant and positive effect on value equity $(\beta=0.578, \mathrm{P}<0.05)$. The result shows that social media marketing activities have a significant and positive effect on relationship equity $(\beta=0.590, \mathrm{P}<0.05)$. The result shows that social media marketing activities have a significant and positive effect on brand equity $(\beta=0.503$, $\mathrm{P}<0.05)$. The result implies that all the social media marketing activities i.e., entertainment, trendiness, interaction, customization, and word of mouth work positively in improving customer equity drivers. The outcome indicated that marketing via social media forums helps in creating customer equity by offering them customized information searching and offering a variety of free content. It also helps them to create interaction among the users and to share their views.

The hypotheses related to the effect of value equity, relationship equity, and brand equity on customer equity are accepted. The result shows that value equity has a significant and positive effect on customer equity $(\beta=0.102, \mathrm{P}<0.05)$. The result shows that relationship equity has a significant and positive effect on customer equity $(\beta=0.212, \mathrm{P}<0.05)$. The result shows that brand equity has a significant and positive effect on customer equity $(\beta=0.506$, $\mathrm{P}<0.05)$. The result implies that when the customer feels connected with the brand, these feeling drives value equity, relationship equity and brand equity which ultimately result in customer equity.

The hypothesis related to the effect of drivers' customer equity i.e., value equity, relationship equity, brand equity on purchase intention is accepted. The result shows that value equity has a significant and positive effect on purchase intention $(\beta=0.489, \mathrm{P}<0.05)$. The result implies that the customer tends to purchase the product based on its objective evaluation i.e., value equity. The relationship equity has a significant and positive effect on purchase intention 
$\beta=0.340, \mathrm{P}<0.05)$. The result implies that the more consumers are familiar with the brand store, brand employees; the perceived relationship equity increases which results in repurchase intention. The brand equity has a significant and positive effect on purchase intention $(\beta=0.308, \mathrm{P}<0.05)$. The result implied that high brand equity generates high purchase intention. It is also stated that customer tends to support their purchase intention based on the brand name.

The last hypothesis related to the effect of purchase intention on customer equity is accepted. The result shows that purchase intention has a significant and positive effect on customer equity $(\beta=0.432, \mathrm{P}<0.05)$. As the relationship between the purchase intention and customer equity is significant, implying that the social media marketing activities could influence customer equity by creating an effect of value equity, brand equity, and relationship equity on purchase intention.

\section{Conclusion}

Social media has become one of the most important forums for finding new information, for generating new social and economic consequences. Apart from this, it is now used by companies for marketing purposes. Despite the importance of social media marketing in various fields very limited research has been done. Therefore, the purpose of this study is to examine how social media marketing efforts influence consumer equity and the intention of brands users in Pakistan. The data is collected from 250 respondents and partial least squares structural equation modeling (PLS-SEM) has been used. The result showed that the entire developed hypothesis is accepted. Social media marketing has a positive and significant relationship with value relationships and brand equity. Moreover, all three drivers i.e., value, relationship, and brand equity have a positive and significant relationship with purchase intention and comer equity. Hence, the study gives valuable implications to brand managers and marketers.

As it is evident from the results that social media marketing activities play a vital role so it is recommended that social media marketers should make their content entertaining and should encourage interaction and engagement. It is also suggested that the consumer should be provided with a forum where they can share their views as it will foster customer equity. The practitioner should fulfill the consumer's motivation related to social media marketing activities as it will increase customer equity. The marketers should make such social media pages that allow customers to feel entertained, give them relevant information and allow them to interact will help in improving the customer equity.

The driver of customer equity also affects the consumer purchase intention of the marketing managers should develop such strategies that result in more value equity, relationship equity, and brand equity. To improve value equity, the organizations should develop products that meet customer expectations and also innovate to find new sources of consumer value. The organizations should focus to improve their value equity drivers i.e., price and quality. The managers should uncover the effect of values drivers on purchase intention for different consumer segments in their business as it will help them to allocate their resources appropriately and also results in maximizing value equity.

The study also highlights that relationship equity also affect the consumer purchase intention so the managers should focus on developing long term relationship with their customers. They should offer promotions to the customer as it will change consumer perceptions and end in word of mouth. Moreover, the relationship equity should also be 
increased by giving special treatment and recognition to the consumers, and corporate loyalty programs, community-building programs should be initiated.

The managers should increase brand equity by raising brand awareness and by approaching new consumers. Furthermore, it is suggested that companies should invest in brand equity as it would strengthen social media marketing activities on customer intentions. Thus, it is of immense importance that brand managers should understand the drivers of customer equity and should know the management of value equity, relationship equity, and brand equity. The understanding of the drivers of customer equity will result in increased customer engagement. Managers should reinforce customer equity drivers in marketing strategies.

\section{References}

[1] E. -J. Seo and J. -W Park, "A study on the effects of social media marketing activities on brand equity and customer response in the airline industry," Journal of Air Transport Management, vol.66, pp.36-41, (2018)

[2] B. Godey, A. Manthiou, D. Pederzoli, J. Rokka, G. Aiello, R. Donvito, and R. Singh, "Social media marketing efforts of luxury brands: Influence on brand equity and consumer behavior," Journal of business research, vol.69, no.12, pp.5833-5841, (2016)

[3] M. Bruhn, V. Schoenmueller, and D. B. Schäfer, "Are social media replacing traditional media in terms of brand equity creation?" Management Research Review, vol.35, no.9, pp.770-790, (2012)

[4] S. Kavisekera and N. Abeysekera, "Effects of social media marketing on the brand equity of online companies." Management and Marketing Journal, vol.14, no.2, pp.201-216, (2016)

[5] Marketing Cloud Com. Everything You Need to Know about Social Media Ads. (2013), Retrieved May, 30, from. https://www.marketingcloud.com/sites/exacttarget/files/Everything-You-Need-to-know-about-SocialMedia-Ads.pdf

[6] https://www.socialmediaexaminer.com/social-media-marketing-industry-report-2018/

[7] A. A. Alalwan et al, "Social media in marketing: A review and analysis of the existing literature," Telematics and Informatics, vol.34, no.7, pp.1177-1190, (2017)

[8] K. Logan, L. F. Bright, and H. Gangadharbatla, "Facebook versus television: Advertising value perceptions among females," Journal of Research in Interactive Marketing, vol.6, no.3, pp.164-179, (2012)

[9] K. Alavijeh and M. Reza, "The effect of customer equity drivers on word-of-mouth behavior with mediating role of customer loyalty and purchase intention," Engineering Economics, vol.29, no.2, pp.236-246, (2018)

[10] A. J. Kim and E. Ko, "Impacts of luxury fashion brand's social media marketing on customer relationship and purchase intention,” Journal of Global Fashion Marketing, vol.1, no.3, pp.164-171, (2010)

[11] C. W. Park, et al, "Brand attachment and brand attitude strength: Conceptual and empirical differentiation of two critical brand equity drivers," Journal of Marketing, vol.74, no.6, pp.1-17, (2010)

[12] V. Gautam and V. Sharma, "The mediating role of customer relationship on the social media marketing and purchase intention relationship with special reference to luxury fashion brands," Journal of Promotion Management, vol.23, no.6, pp.872-888, (2017)

[13] K. Sano, "Do social media marketing activities enhance customer satisfaction, promote positive WOM and affect behavior intention,” Doshisha Commerce Journal, pp.3-4, (2014)

[14] M. Yadav and Z. Rahman, "Measuring consumer perception of social media marketing activities in ecommerce industry: Scale development and validation,” Telematics and Informatics vol.34, no.7, pp.12941307, (2017)

[15] M. Yoshida and B. Gordon, "Who is more influenced by customer equity drivers? A moderator analysis in a professional soccer context," Sport Management Review, vol.15, no.4, pp.389-403, (2012)

[16] C. L. Yuan, J. Kim, and S. J. Kim, "Parasocial relationship effects on customer equity in the social media context," Journal of Business Research, vol.69, no.9, pp.3795-3803, (2016) 
[17] V. A. Zeithaml, K. N. Lemon, and R. T. Rust, "Driving customer equity: How customer lifetime value is reshaping corporate strategy," Simon and Schuster, (2001)

[18] B. G. Tabachnick and L. S. Fidell, "Multivariate analysis of variance and covariance," Using multivariate statistics, vol.3, pp.402-407, (2007)

[19] J. Hair et al, "Multivariate data analysis," Prentice-Hall Englewood Cliffs

[20] C. Fornell and D. F. Larcker, "Evaluating structural equation models with unobservable variables and measurement error,” Journal of Marketing Research, vol.18, no.1, pp.39-50

[21] D. Gefen and D. Straub, "A practical guide to factorial validity using PLS-Graph: Tutorial and annotated example," Communications of the Association for Information systems, vol.16, no.1, pp.5, (2005)

[22] J. Henseler, C. M. Ringle, and M. Sarstedt, "A new criterion for assessing discriminant validity in variancebased structural equation modeling," Journal of the Academy of Marketing Science, vol.43, no.1, pp.115-135, (2015)

[23] D. -Y. Kim and H. -S. Yoo, “A study on consumer acceptance of one-person media content-based advertising," Asia-pacific Journal of Convergent Research Interchange, FuCoS, ISSN: 2508-9080 (Print); 2671-5325 (Online), vol.7, no.3, pp.19-28, March, (2021), http://dx.doi.org/10.47116/apjcri.2021.03.02

[24] H. Sun and B. Yuan, "Research on marketing strategy of social network media based on big data analysis," International Journal of Database Theory and Application, vol.9, no.10, pp.261-270, (2016)

[25] T. Hendratono, S. Supina, M. Syafulloh, A. Priyono, and Damiasih, "The influence of advertising, price, and e-service quality to repurchase intension to online travel agent users," International Journal of Advanced Science and Technology, vol.130, pp.140-150, (2019)

[26] M. Natarajan and Manimaran, "Impact of advertisement on buying behavior of rural women consumers," International Journal of $\mathrm{u}$ - and e-Service, Science and Technology, vol.9, no.6, pp.11-22, (2016) 
The Impact of Social Media Marketing Activities on Consumer Equity: Evidence from Luxury Brand

This page is empty by intention. 